\title{
Research Paper \\ Comparison of Marital Satisfaction, Parenting Styles and Attachment Styles in Parents of Children with and without Nail Biting
}

\author{
Fatemeh Gholami $^{* 1}$, Ahmad Ghanizadeh ${ }^{2}$, Gholamreza Dehbozorgi ${ }^{3}$
}

1. M.A. in Clinical Psychology, Faculty of Medicine, Shiraz University of Medical Sciences, Iran

2. Associate Professor, Department of Psychiatry, Faculty of Medicine, Shiraz University of Medical Sciences, Iran

3. Assistant Professor, Department of Psychiatry, Faculty of Medicine, Shiraz University of Medical Sciences, Iran

Citation: Gholami F, Ghanizadeh A, Dehbozorgi G. Comparison of marital satisfaction, parenting styles and attachment styles in parents of children with and without nail biting. Quarterly Journal of Child Mental Health. 2020; 7(1): 168-180.

\section{http://dx.doi.org/10.29252/jemh.7.1.15}

\section{A R T I C L E I N F O}

\section{Keywords: \\ Nail biting, marital satisfaction, parenting style, attachment style}

Received: 11 Jun 2018

Accepted: 21 Jun 2019 Available: 20 Jun2020

\section{A B S T R A C T}

Background and Purpose: Nail biting is a common behavior in children that may be connected to some environmental factors like parental problems or parenting styles. The purpose of this study was to compare marital satisfaction, parenting style, and attachment style in parents of children with and without nail biting.

Method: This research was a descriptive cross-sectional study. The population consisted of all preschool and primary school students with nail biting behaviors in Shiraz in 2015. To select a sample (284 parents), 10 schools were selected from each area of Shiraz by cluster sampling and then 40 preschool and primary school students were selected from each school by convenience sampling. Afterwards, their parents were asked to complete ENRICH Marital Satisfaction Scale (Olson, 1989), Baumrind's Parenting Styles Questionnaire (Baumrind, 1972), and Revised Adult Attachment Scale (Collins \& Read, 1996). Data were analyzed by T-tests and Multivariate Analysis of Variance (MANOVA) by using SPSS Version 24 Software.

Results: Results demonstrated that there was no significant difference between mothers of the nail biting and control groups in terms of marital satisfaction, parenting style, and attachment style at $\mathrm{P}>0.05$. Also, no such a difference was found between the fathers.

Conclusion: Based on the results of this study, it can be suggested that nail biting behavior may be directly or indirectly influenced by some variables that deserve further investigations.

\footnotetext{
* Corresponding author: Fatemeh Gholami, M.A. in Clinical Psychology, Faculty of Medicine, Shiraz University of Medical Sciences, Iran. E-mail addresses: Gholamif75@gmail.com
} 


\section{مقايسه رضايتمندى زناشويى، سبكهاى دلبستكى، و سبككهاى والدكرى والدين كودكان با و بدون مشكلات ناخن جويدن}

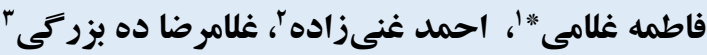

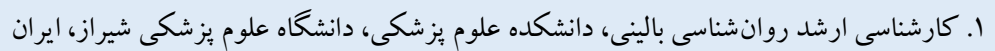

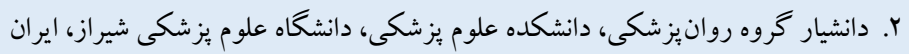

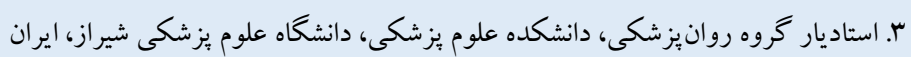

زمينه و هدف: ناخن جويدن رفتارى شايع در كود كان است كه مى تواند با برخى از عوامل محيطى مانند مشكلات والدين و ويا سبككهاى

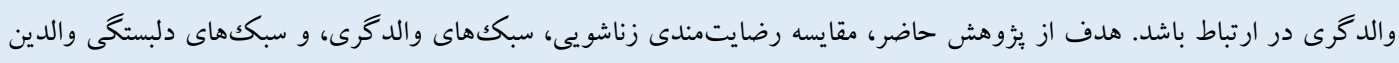
كود كان با و بدون مشكلات ناخن جويدن بود. روش: طرح يُوهش حاضر، توصيفى از نوع تحليل مقطعى است كه جامعه آمارى آن شامل تمامى والدين دانش آموزان بيشددبستانى و و

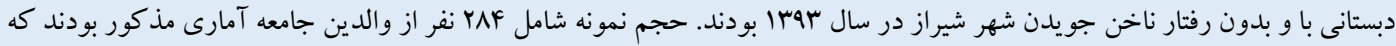

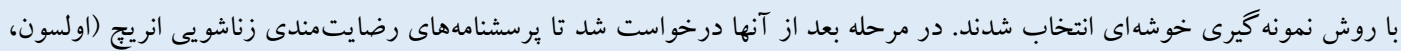

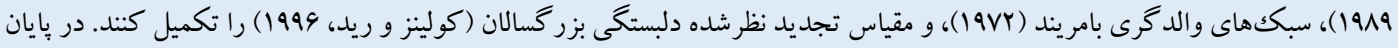

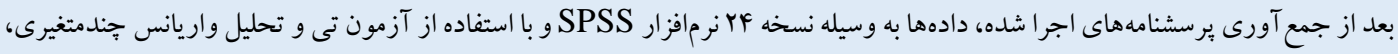
وارسى و تحليل شدند. يافتهها: يافتهها نشان داد بين مادران دو گروه كودكان با و بدون بان رفتارهاى ناخن جويدن، تفاوت معنادارى در سبكهاى والدكرى،

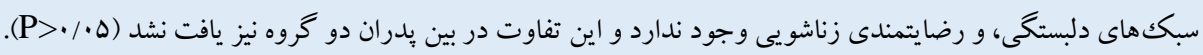
دريافت شده: (

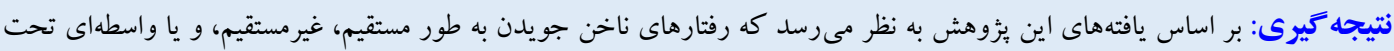

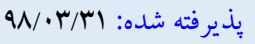

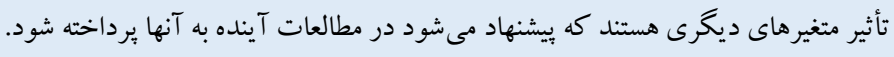

مشخصات مقاله

كليدوازهها:

ناخن جويدن، رضايتمندى زناشويى، سبك هاى والدگرى، سبك هاى دلبستخى والى كرى،

* نويسنده مسئول: فاطمه غلامى، كارشناسى ارشد روانشناسى بالينى، دانشكده علوم يزشكى، دانشكاه علوم يز شكى شيراز، ايران. رايامه: Gholamif75@gmail.com 
خو اهند كرد يا بعدها از اين مشكل رنج نخو اهند برد، اما حتى كود كانى

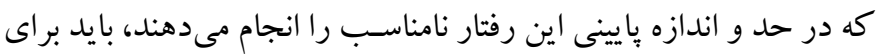
مديريت مشكل خود، آموزشهاى للازم را دريافت كنند (V).

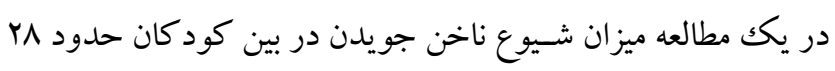

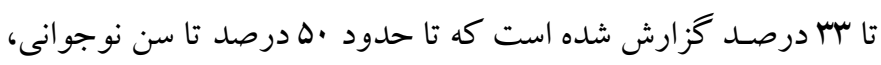

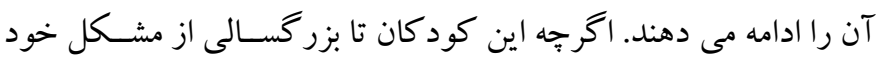

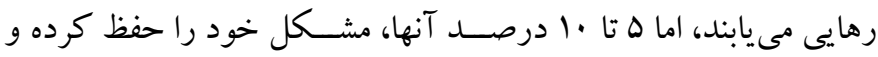
ادامه مىدهند (^). ميز ان ناخن جويدن در كود كان هفت سـاله در حدود

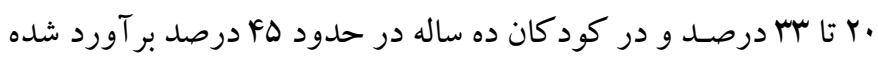

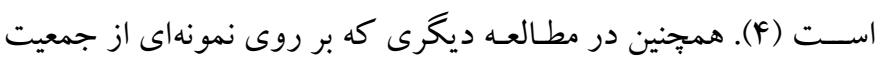

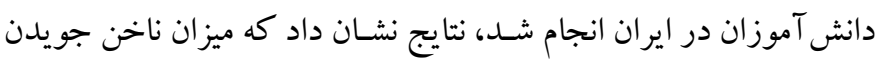

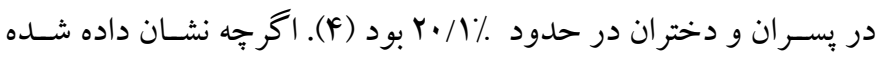

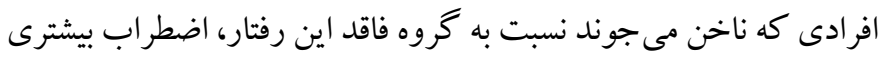

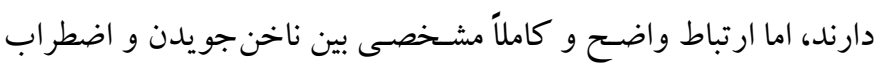

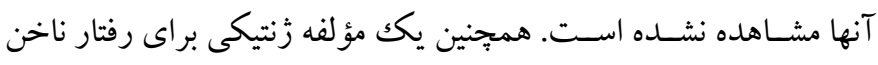
جويدن مطرح شـده اسـت؛ به طورى كه اين رفتار در دو سوم دوقلوهاى

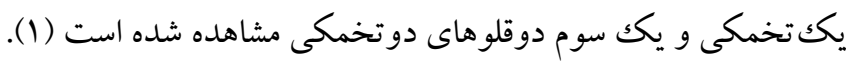

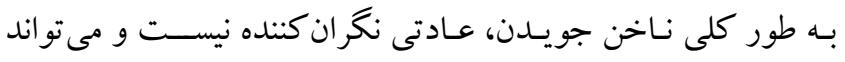

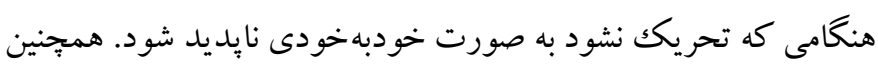

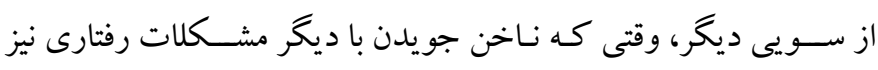

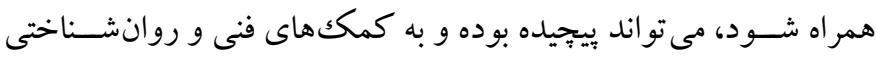
خاص نياز داشته باشد (V). برخى عو امل در بيدايش و تداوم رفتار ناخن

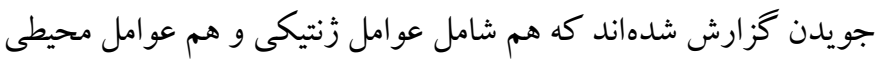

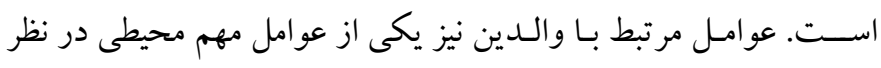

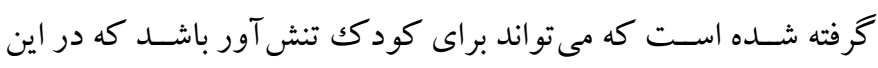

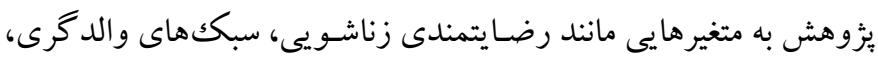

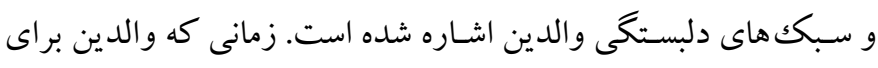

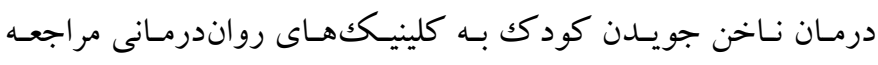

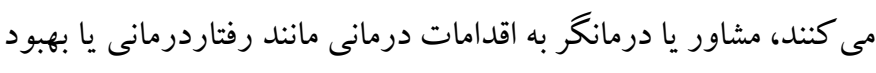

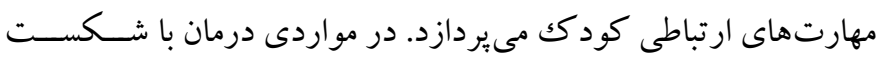

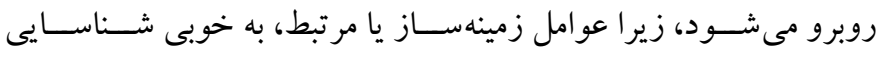

مقدمه بسـيارى از افراد بهنجار حتى بزر گســالان، در برخى از زمانها كه دجار

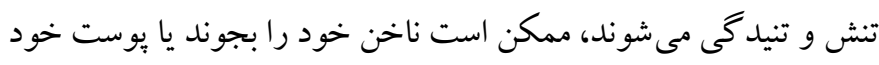

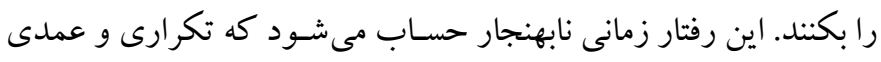

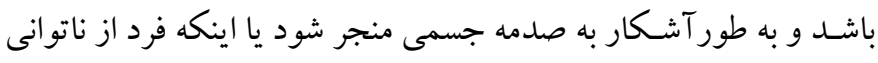

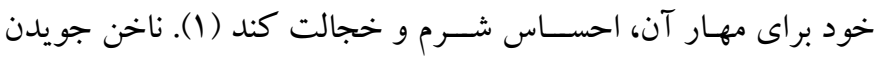
'رفتارى در بين كود كان و بزر گسـالان كمسـن اسـت كه بسـيار فراوان

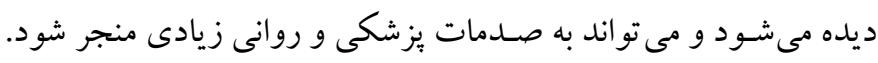

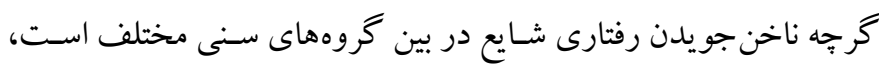

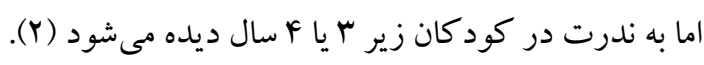
اونيكوفاجيا'، اصطلاح ديخرى است كه به جاى ناخن جويدن به كار

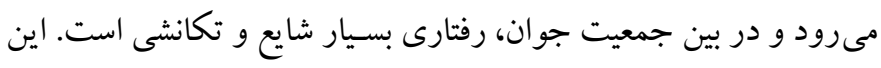

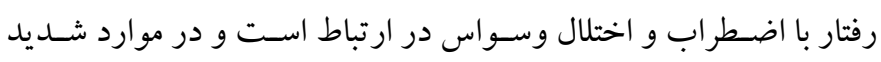

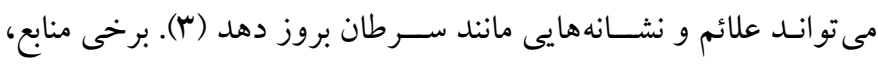

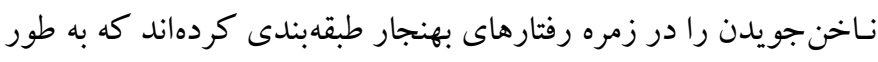

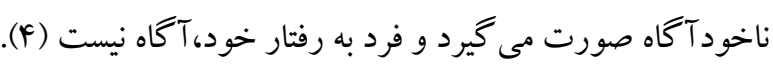

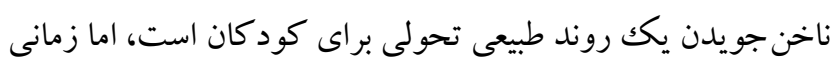

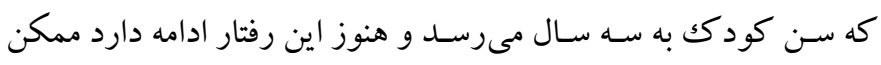

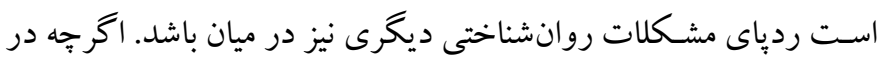

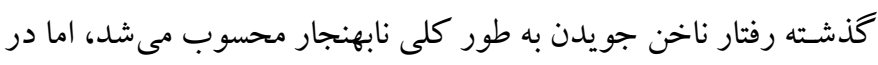

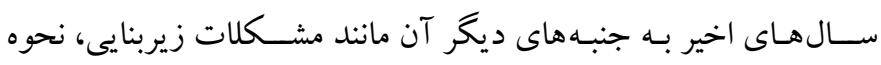
مداخله، و نظاير آن توجه مىشود (ه).

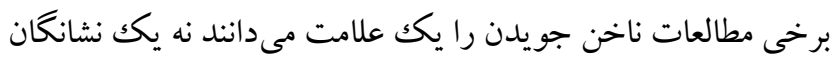

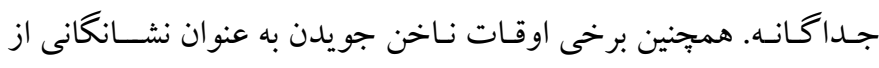

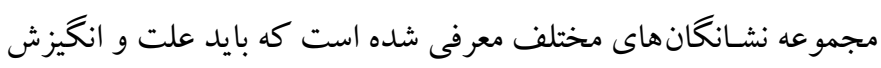

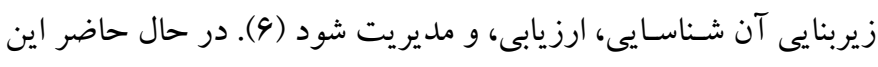

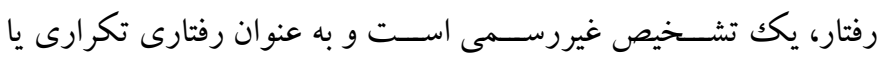

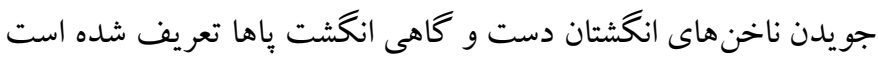

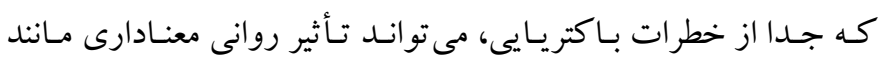

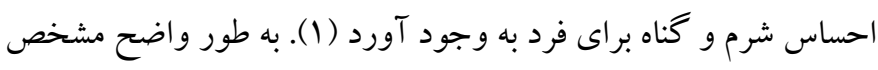

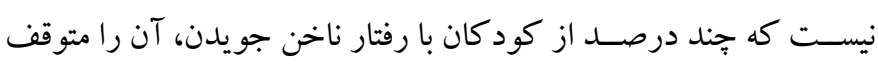

1. Nail biting 
سـبك هاى والدگرى * متغير ديخرى است كه مى تواند يكى از عو امل

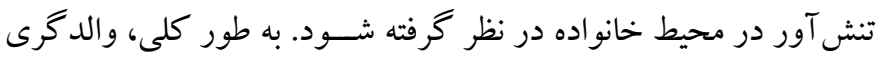

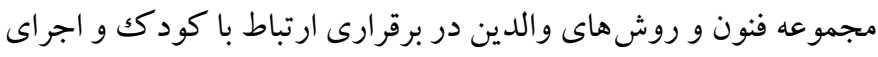

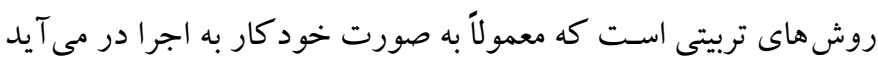

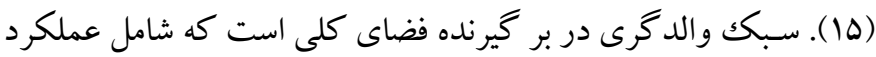
خانو اده مانند شــكل دهى رفتارهاى كود كك به وســــله والدين يا مر اقبان

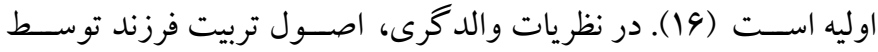

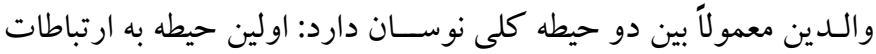

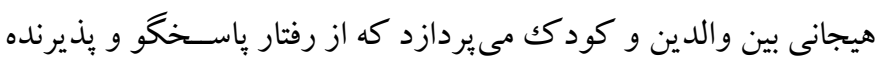

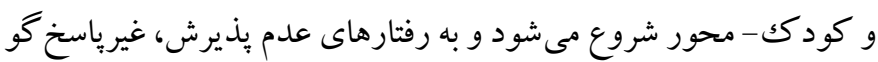
و والد- محور ختم مى شــود. با تركيب اين دو بعد (يذيرش بالا در برابر

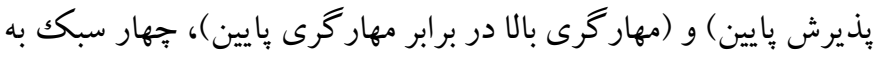

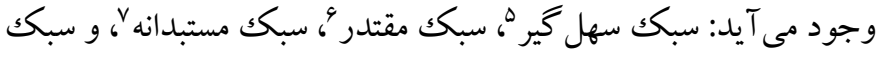

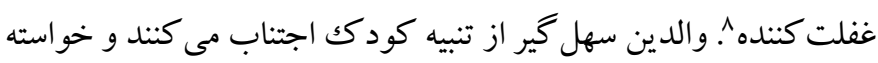
هـا، تمـايلـات، و رفتـارهـاى كود كك را مى يـذيرند. والدين مقتدر تمايل

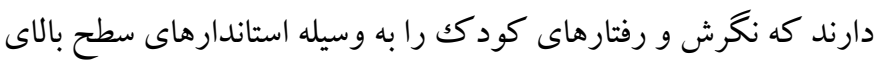
خانو اد گى ارزيابى، مهار، و شـكل دهى كنند كه به وسسيله مراجع قدرت

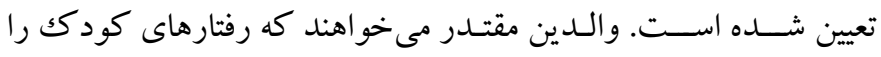
سـازماندهى كنند، اما به وسـيله يكك روش مســالمت آميز و دوســتانه.

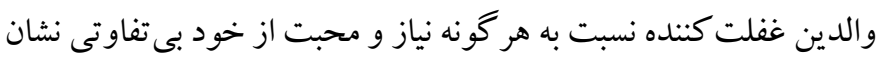

مى دهند (IV) ( ) (IV).

عوامل بسيارى در گر ايش والدين به سبك والدگرى خاص ذكر شده

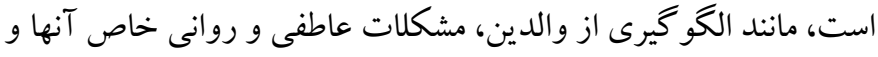

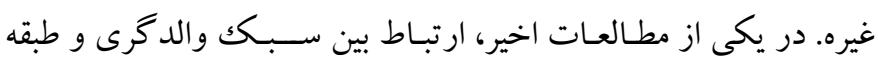

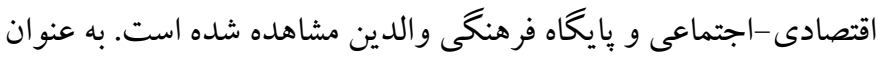

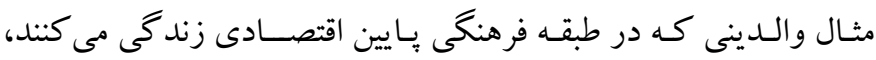

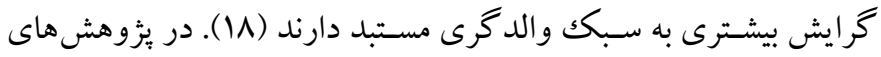

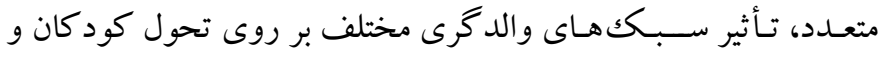
نوجوانان و اختلالات رفتارى آنها نشان داده شده است. به عنوان مثال در

8. Neglective style
نمىشود. للازم به ذكر است كه عوامل مرتبط با والدين نيز مىتواند مهم و

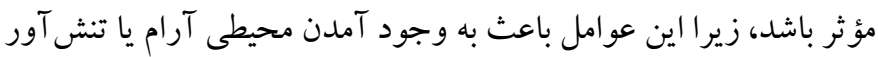

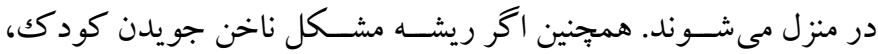

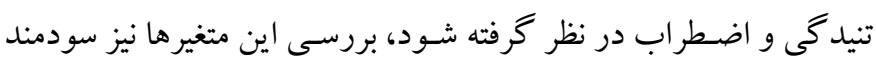

رضـايتمنـدى زنـاشـــويى' يكى ديخر از عوامـل مهم محيط زندكى

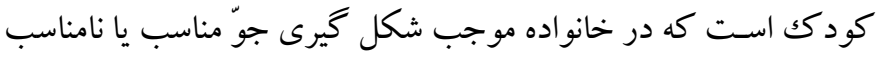

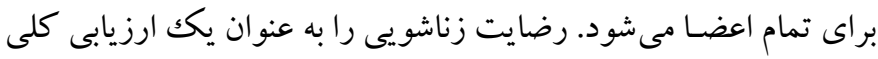
از وضعيت زناشويى توسط فرد و بازتابى از شادمانى و كاركرد زناشويى،

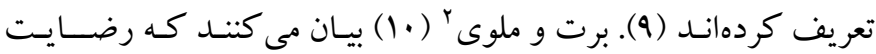

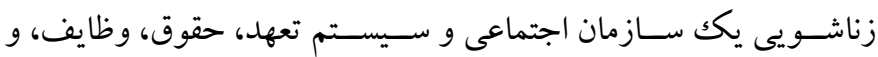

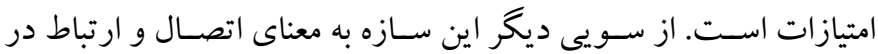
جهت دوست داشتن و اعتماد كردن به يك فرد براى صميميت جنسى و

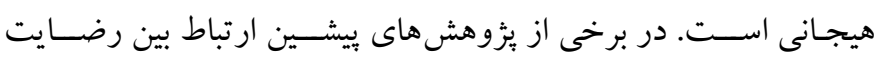

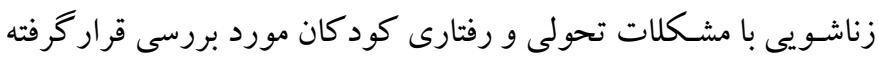
است. به عنوان مثال، رضايتمندى مادران كود كان كم توان ذهنى به طور معنادارى، يايين تر از والدين كود كان بهنجار گز ارش شــــه اسـت (11).

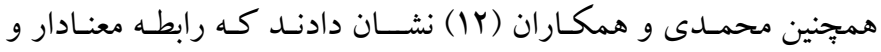

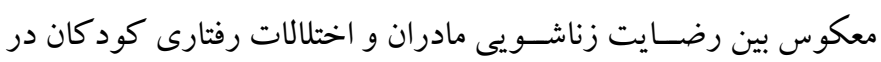

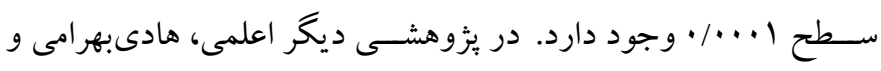

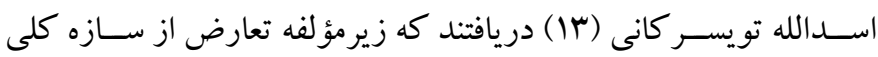

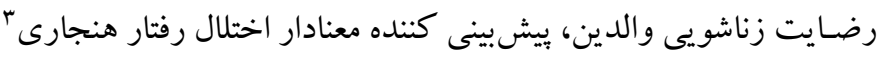

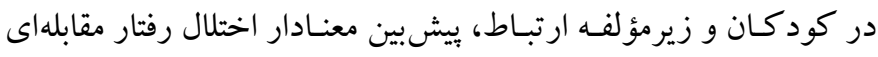

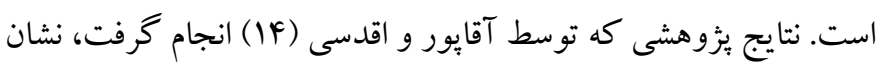

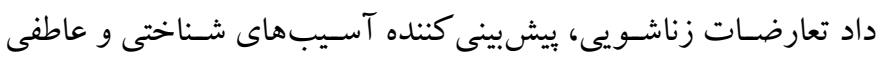
كود كان است. بر اين اساس سوالى كه بيش مى آيد اين است كه آيا بين

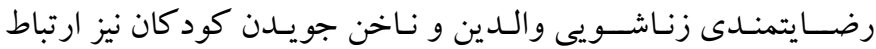

1. Marital satisfaction

2. Bert \& Melvey

3. Conduct disorder

4. Parenting styles 


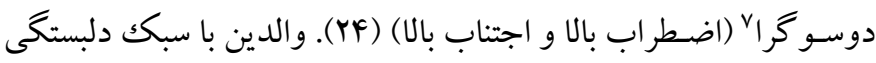
ناايمن، معمولاً در برابر كود كان خود نيز رفتار مشــابهى در بيش كرفته و آنها را در برابر تجـارب محيطى يـا جدايىهاى كوتاهمدت به تنيدكى و اضـطر اب مبتلا مى كنند كه مى تواند زمينه بروز برخى اختلالات رفتارى را در آنها ايجاد كند. در بزّوهش هاى بيشـين ارتباط سـبك دلبستـى والدين با مشـكلات رفتـارى كود كـان مورد بررسـى قرار گرفتـه اســت. براى مثال هاوارد،

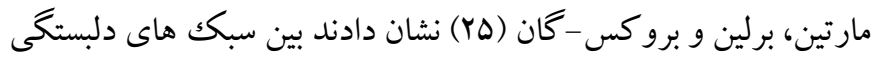
نايمن -اضـطرابى و نايمن -اجتنابى مادر و همجنين تعداد ســاعات جـدايى مـادر از كودكك با مشـكلات بعدى فرزند، ارتباط مثبت و معنى دارى وجود دارد، امـا نوع اين مشــكلـات رفتـارى بـه طور خاص

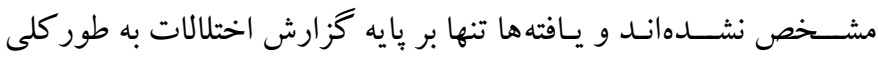

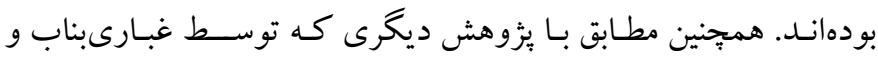
اسـتيرى (Y4) انجام شـد در متغير سـبك دلبسـتخى بين مادران كود كان بهنجار و مادران كود كان مبتلا به اختلال طيف اوتيســم، تفاوتى وجود نداشت. قابل ذكر است كه در بيشتر يزوهش ها، رابطه سبك والدگرى با اختلـالـات تحولى كودكى مورد توجه و بررسـى قرار گرفتهاند و درباره اختلالات رفتارى به خصـوص ناخن جويدن، يزٔوهشى انجام نشـده است. همجنين بايد توجه داشـت كه نمونه هاى بزُوهش عمدتاً بر روى مادران انجام شده است و بدران مورد بررسى قرار نخرفتهاند؛ بنابر اين سو ال مهم اين اسـت آيا بين سـبكهاى دلبستگى، سبك هاى والدگرى، و رضايت زنـاشـــيى والدين كود كان با و بدون مشـكلات رفتارى ناخن جويدن،

تفاوت وجود دارد؟

روش الف) طرح يزوهش و شر كت كنند كان: اين بزوهش از نوع توصيفى -

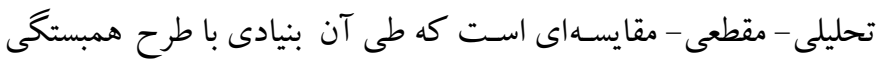

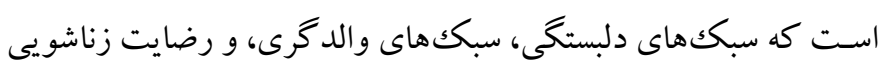

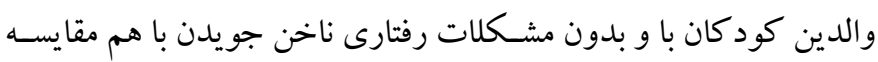
شــه اسـت. جامعه آمارى اين مطالعه شـامل تمامى و الدين دانش آموزان
يكك مطالعه توسط بورنستين و بورنستين (19) بر روى كود كان و والدين

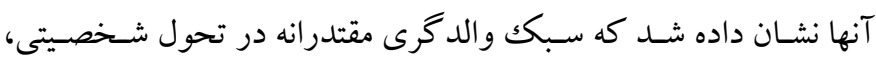

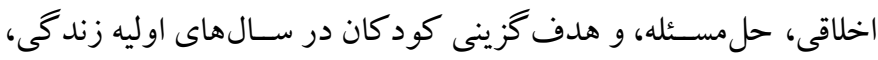

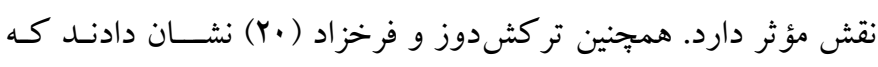

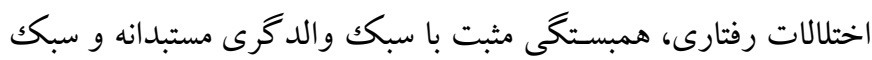

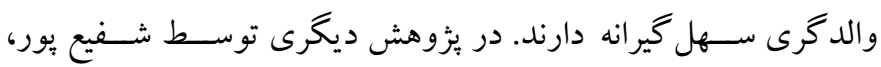

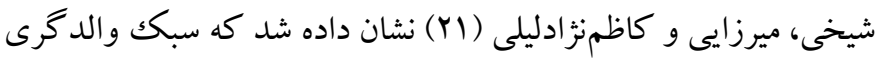

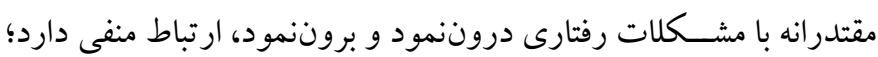

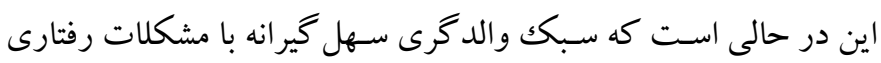
دروننمود، ارتباط مثبت دارد. علاوه بر سـبك هاى والدگرى، سـبك دلبستِكى ' والدين نيز از ديكر عو املى است كه به نظر مىرسد با مشكلات رفتارى فرزندان مرتبط باشد.

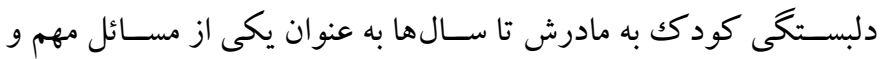

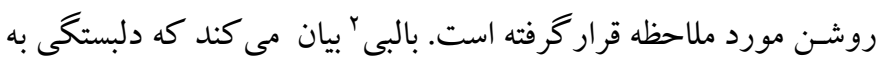

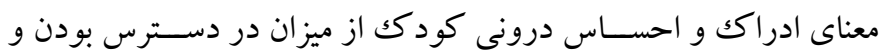

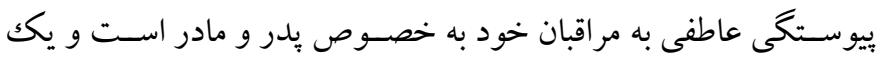

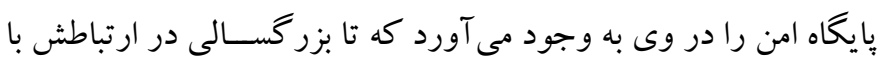

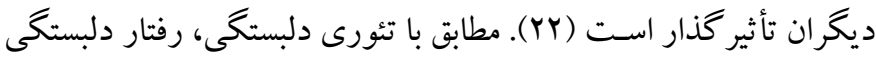

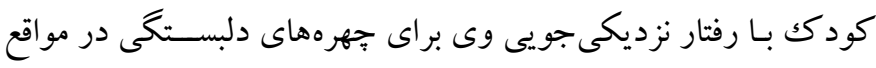

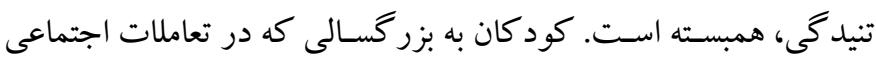
در برابر آنها حسـاس و ياسخخگ است، دلبسته مى شوند و اين بزر كسالان خصـوصاً از 9 ماهكى تا ب سـالكى، مر اقب اصلى كود وك باقى مى مانند.

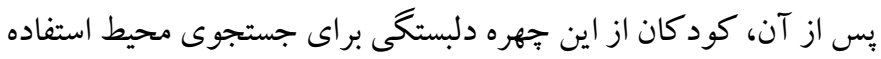

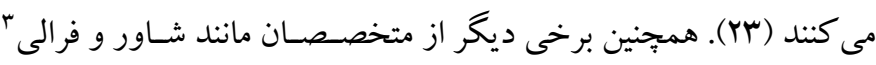
(Y...F)

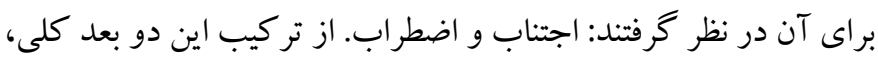

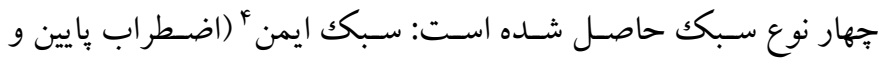

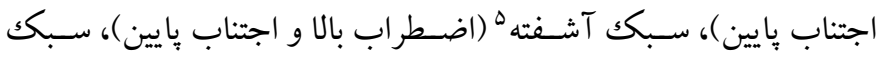

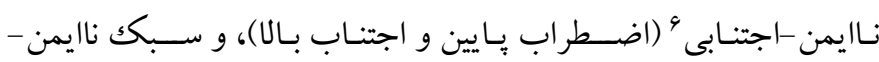

1. Attachment style

2. Bowlby

3. Shaver \& frally, 2004

4. Secured attachment style 
نشـاندهنده رضـايت بسـيار زياد اسـت. اولسـون يايايى برسشنامه را براى

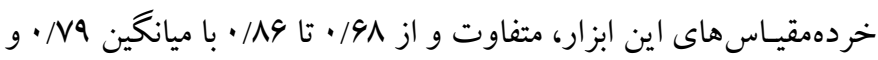

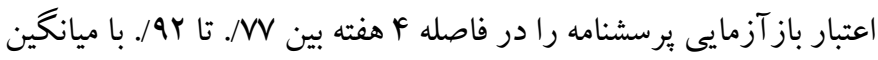

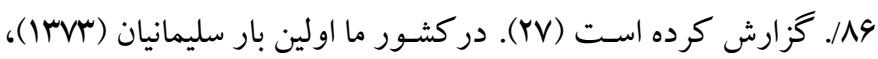

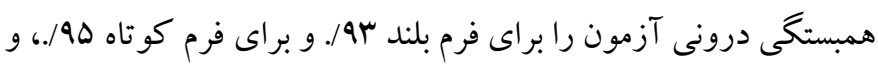

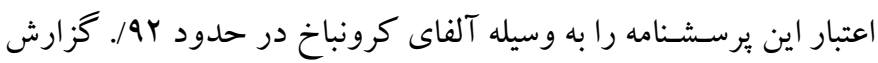
كرده است (به نقل از YV).

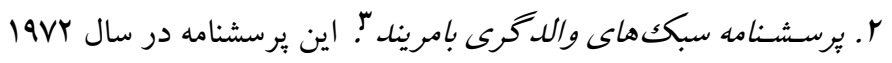

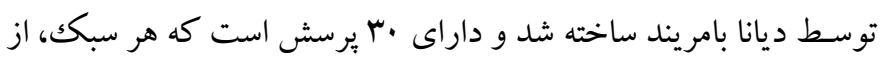

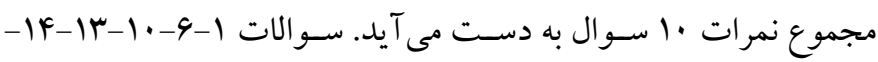

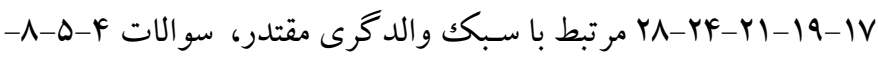
11 㑭

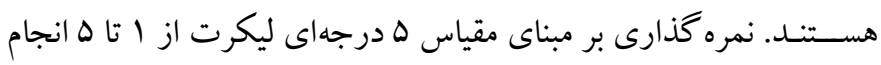

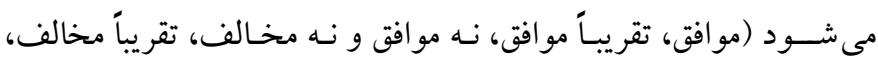

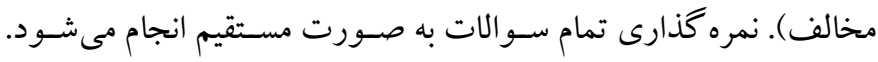

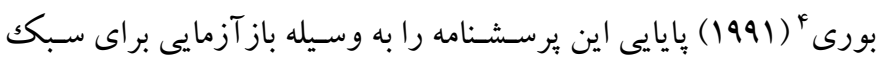

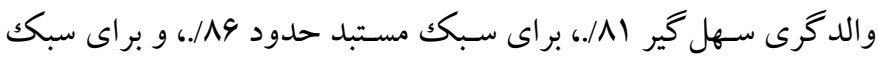

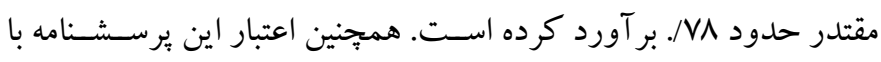

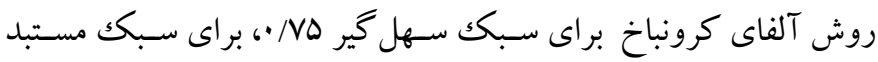

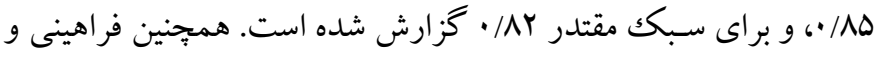
همكاران اعتبار برسشــامه را از طريق آلفاى كرونباخ براى سبكك مستبد

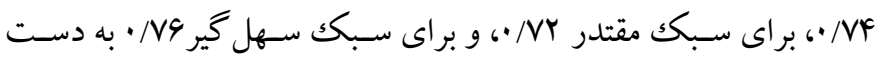

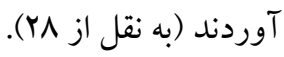

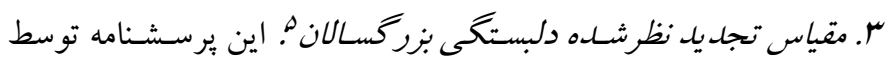

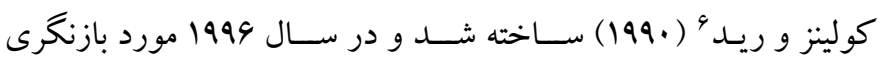

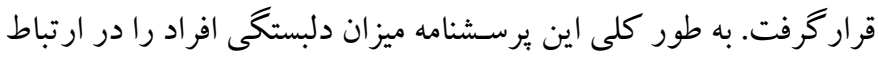

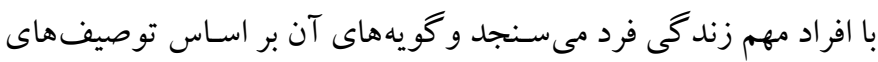

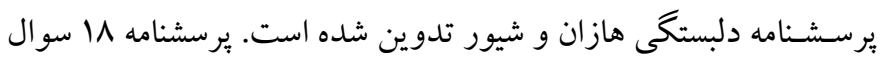

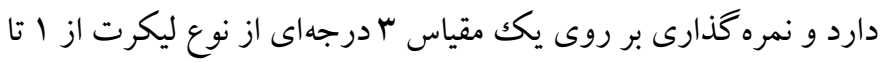

\section{Bouri, 1991}

5. Revised Adult Attachment Styles Scale (RAAS)

6. Collins \& Rid,1990
بيش دبستانى و دبستانى با و بلون رفتارهاى ناخن جويدن در شهر شيراز

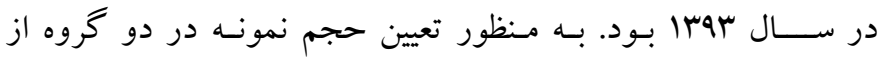

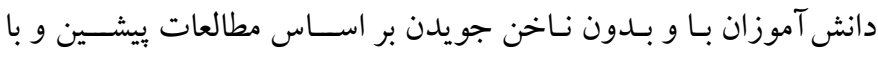

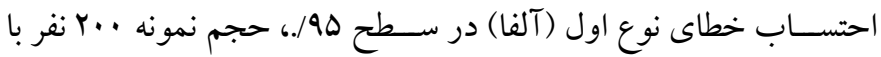

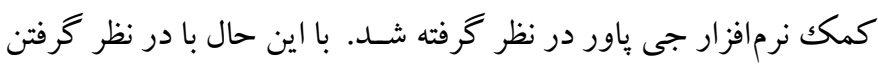

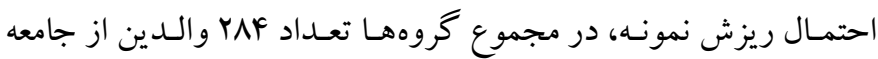
آمارى مذكور انتخاب شده و دادههاى للزم از آنها جمع آورى شد. بدين

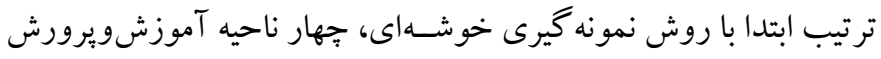

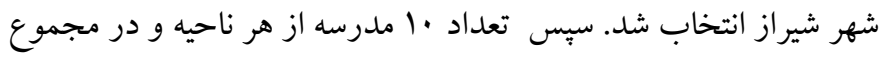

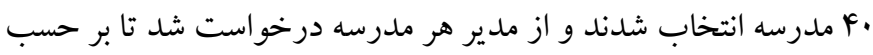

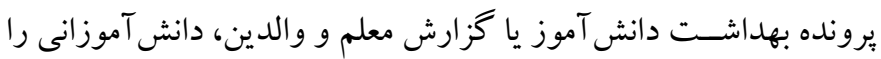

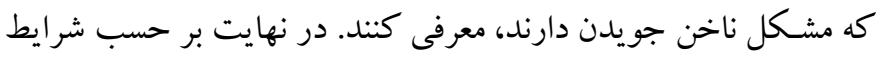
ورود و خروج، افراد نمونـه از ميـان دانش آموزان معرفى شــــه، انتخاب

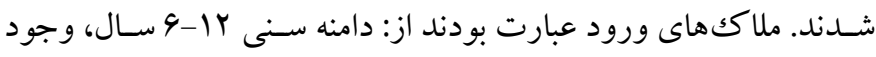

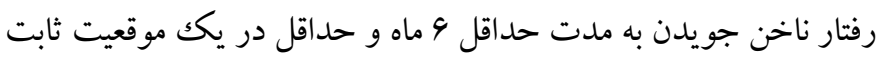

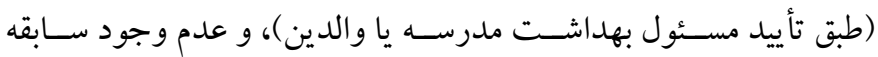

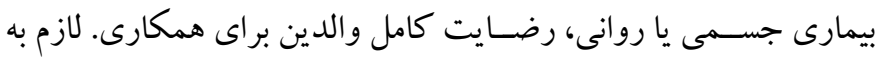

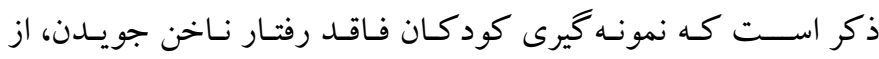
دانش آموزانى انجام شـــ كه هيج كدام از ملاككهاى رفتار ناخن جويدن

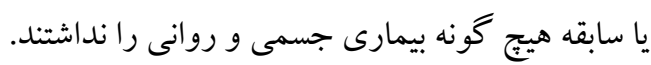
ب) (بزار

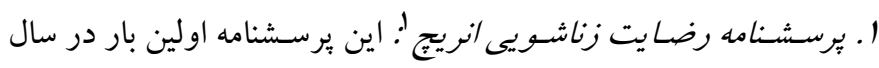

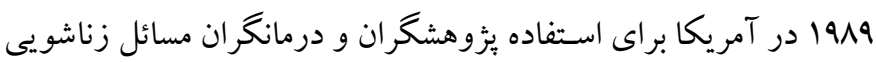
زناشويى ساخته شد و در سال 1919 جهت تعيين بايايى و روايى، مورد

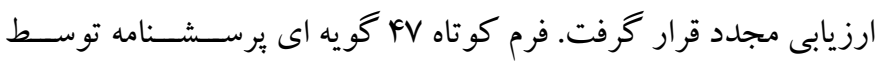

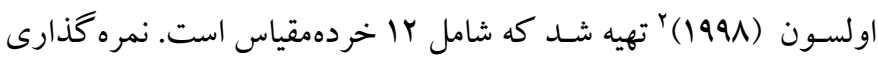

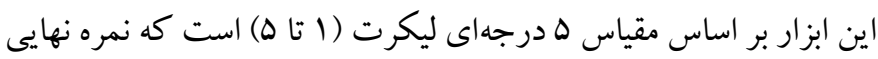

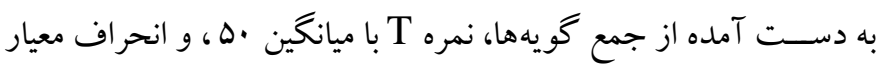

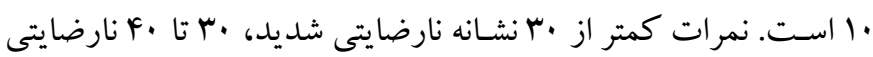

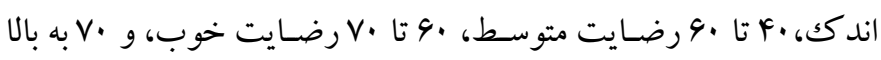

1. Enrich Marital Satisfaction Questionnaire

2. Olson, 1998

3. Baum rind Parenting Styles Questionnaire (BPSQ) 
ســس با رجوع به آموزشويرورش ناحيه ا تأF شـهر شـيراز، فهرسـت مدارس ييش دبستان و دبستانى شهر شيراز دريافت شد. در نهايت بعد از

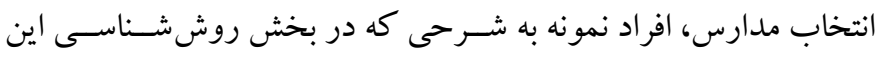

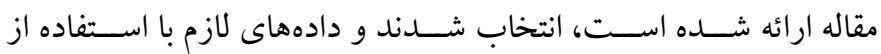

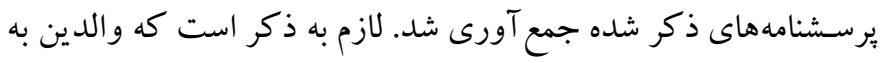

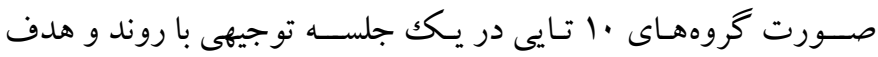

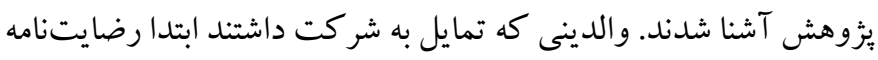

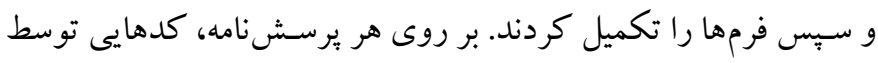

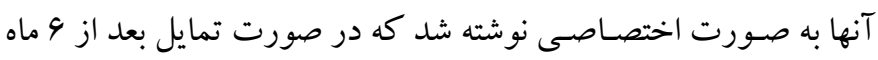

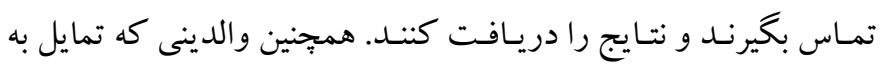
دريافت مشـاوره و رواندرمانى بودند به مركز تخصسصى معرفى شــند.

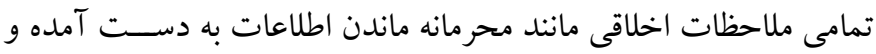

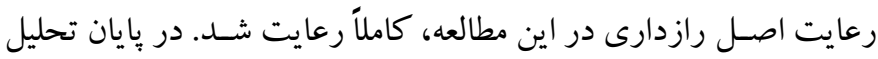

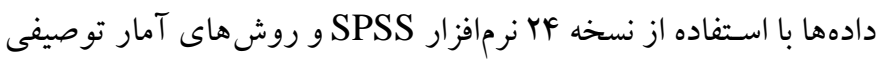

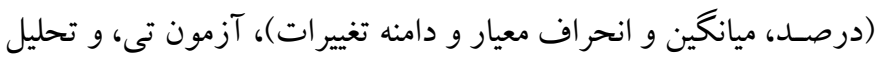
واريانس جندمتغيرى انجام شد.

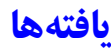
تحليـل دادهها در اين مطالعه روى ع بـ نفر از والدين دانش آموزان انجام

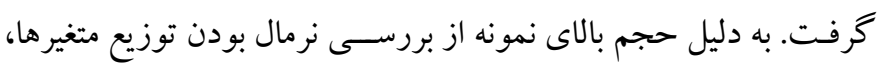

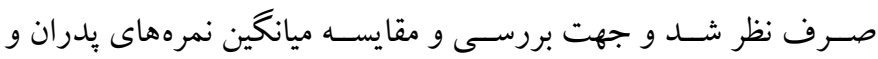
مادران در رضايتمندى زناشويى از آزمون تى خروههاى مستقل استفاده شـــ جدول ا نتايج مقايسـه رضـايت مندى زناشـويى دو نمونه مادران و

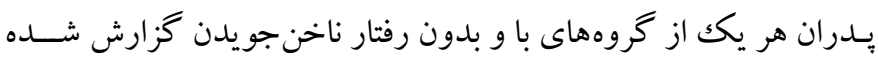

ץ (موافقم، نه موافقم و نه مخالفم، مخالفم) انجام مىشود. سوالات مربوط

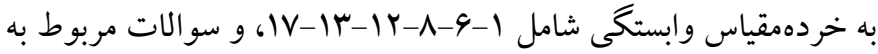
خردهمقياس نزديكىجو شـامل Y-ه-V-Y

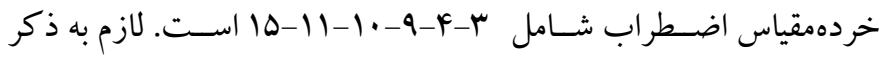

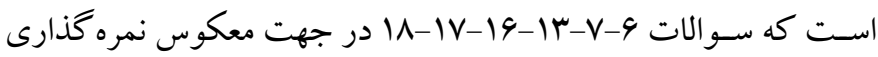
مىشوند. اين مقياس داراى سه خردهمقياس است: وابستخى (D)' ': درجه اعتماد بين افراد كه مطابق با سبكك دلبستخى نايمن /دوسو گرَا در تئورى

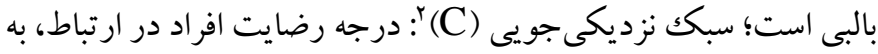

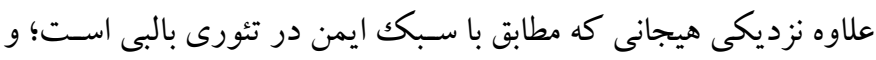

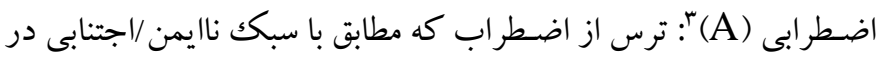
تئورى بالبى اسـت. اعتبار آزمون توسـط يُزوهش كولينز و ريد به وسـيله

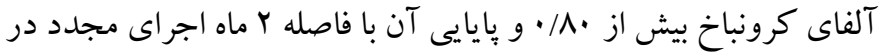

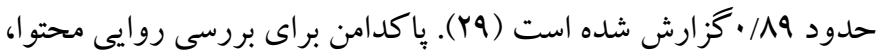

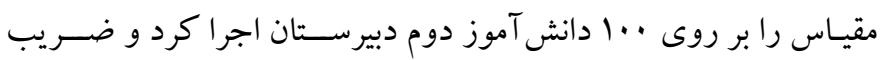

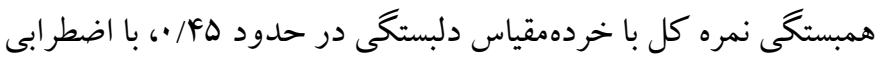

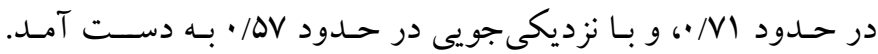

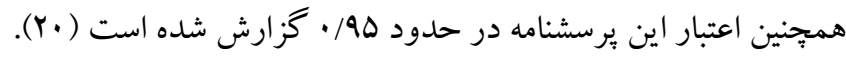

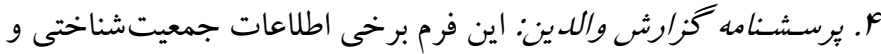

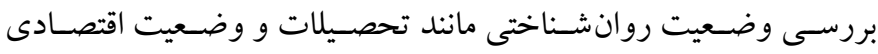

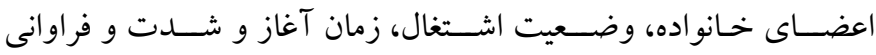
ناخن جويدن كودك،، سابقه بيمارى جسمانى و روانى فرزندان خانو اده و والـدين، دريـافت و عـدم دريـافت خدمات رواندرمانى و مشــاوره در كذشته و زمان حاضر را مورد بررسى قرار داده است.

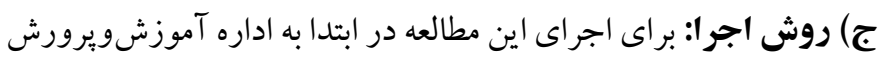

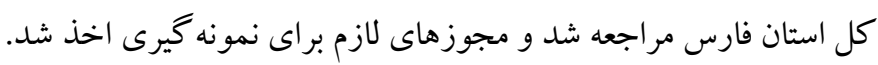


جدول ا: نتايج آزمون t جهت مقايسه ميانكين رضايتمندى زناشويى مادران و يدران دو كروه

\begin{tabular}{|c|c|c|c|c|c|c|c|}
\hline سطح معنى & درجه آزادى & $\mathbf{t}$ & خطاى معيار ميانكين & انحر اف معيار & 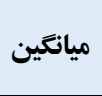 & تعداد & كروهاها \\
\hline \multirow{2}{*}{$\cdot /$ Y99 } & \multirow[t]{2}{*}{10.} & \multirow{2}{*}{$-Y / \Delta 91$} & $r / 91$ & rI/9. & $1 r \cdot / 9$. & 90 & مادران دانش آموزان با رفتار ناخن جويدن \\
\hline & & & $r / 11$ & $r q / \cdot r$ & $1 \cdot N / r r$ & $\wedge \vee$ & مادران دانش آموزان فاقد رفتار ناخن جويدن \\
\hline \multirow{2}{*}{.1991} & \multirow{2}{*}{ ir. } & \multirow{2}{*}{$-\cdot / 109$} & $r / \cdot r$ & $r \Delta / T V$ & $\mid r g / \pi \Lambda$ & 99 & يدران دانش آموزان با رفتار ناخن جويدن \\
\hline & & & $r$ & $r r / \Lambda 1$ & ITA/NY & 94 & يدران دانش آموزان فاقد رفتار ناخن جويدن \\
\hline
\end{tabular}

سبكك مستبد( •//•)، و سبكك سهل گير (TV/•) در هر دو گروه (يدران و

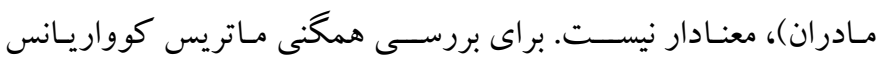

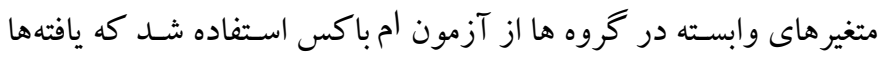

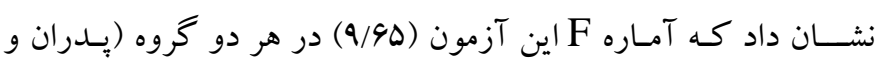

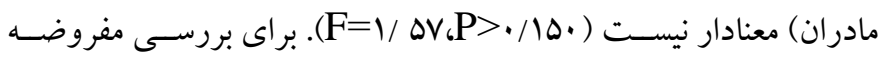

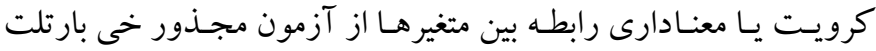

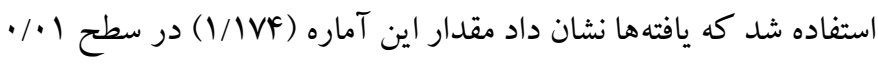
رابطه معنى دار اسـت؛ بنابر اين بين متغيرهاى يزوهش رابطه معنادار وجود ئهد

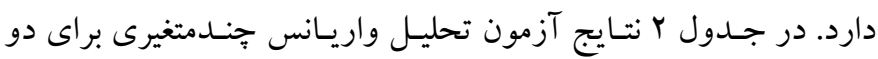

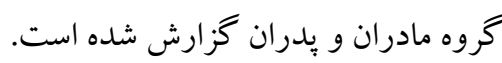

بر اساس نتايج ارائه شده در جدول ا، بين نمرات مادران گروه ناخن

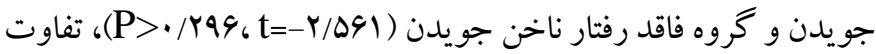

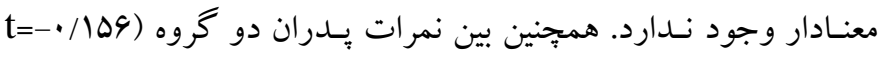

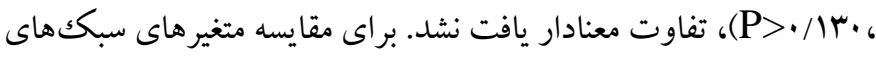

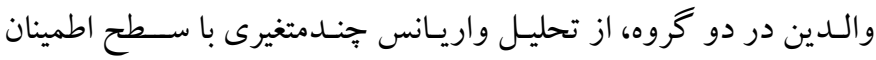

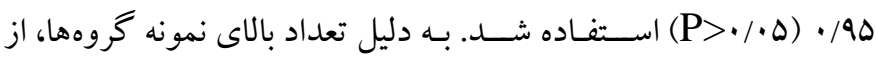
بررسى نرمال بودن توزيع متغيرها صـرف نظر شـد. قبل از ازائه نتايج اين

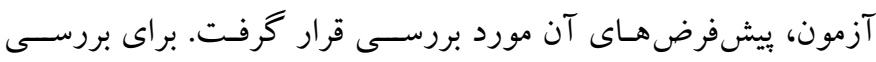

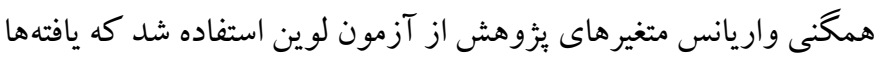

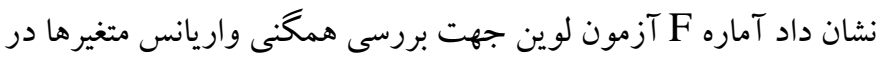

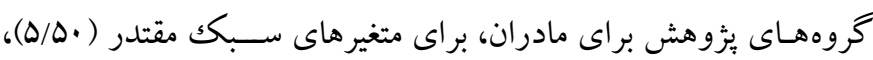

جدول r: نتايج آزمون تحليل واريانس جندمتغيرى مربوط به والدكرى در مادران و يدران دو كروه

\begin{tabular}{|c|c|c|c|c|c|c|c|}
\hline اندازه اثر & سطح معنى دارى & d.f1 & d.f1 & $\mathbf{F}$ & آماره & آزمون & كروه \\
\hline.$/ \cdot 11$ & . / FTA & IFV & $r$ & $\cdot / 9 \cdot 9$ &.$/ \cdot 11$ & اثر ييلايى & مادران \\
\hline.$/ \cdot 11$ & . $/$ Kr & IFV & $r$ &.$/ 9.9$ & . /QAY & لامبداى ويلكز & \\
\hline.$/ \cdot 11$ & . & IFV & $r$ &.$/ 9.9$ &.$/ .19$ & اثر هاتلينك & \\
\hline.$/ \cdot 11$ & $\cdot /$ kTh & IFV & $r$ & $\cdot / 9 \cdot 9$ &.$/ .19$ & بزر كترين ريشه روى & \\
\hline ./.r. & . /GGF & IrA & $r$ & $\cdot / \wedge \Delta Q$ & $\cdot / \cdot r$ & اث سلاري & بدران \\
\hline.$/ . r$. & . /4aq & $\begin{array}{l}\text { ITA } \\
\mid T A\end{array}$ & $\begin{array}{l}r \\
r\end{array}$ & - /NDQ & $\begin{array}{l}. / 94 . \\
. / . r .\end{array}$ & لامبداى ويلكز & \\
\hline $\begin{array}{l}. / \cdot r \\
. / \cdot r\end{array}$ & $\begin{array}{l}. / 494 \\
. / 494\end{array}$ & IrA & $r$ & $\begin{array}{l}\cdot / \wedge \Delta Q \\
\cdot / \wedge \Delta Q\end{array}$ &.$/ . r$. & بزر برترين ريشه روى & \\
\hline
\end{tabular}

والـدكرى، بين ســــك مادران كود كان با و بدون رفتار ناخن جويدن و يــدران كودكـان بـا و بــدون رفتـار ناخن جويدن، تفاوت معنادارى وجود نداشته است.
بـا توجسه بـه نتـايج جـدول Y، آمـاره F تحليـل واريانس جندمتغيرى بررسـى تفاوت گرووهها در ســبك والدگرى، در هيج كدام از آزمونها معنى دار نيســـ؛ بنابر اين مى توان كفت كه بين كروهها در ســـك هـاى والـدكرى مـادران و يــدران تفـاوت وجود ندارد. به بيانى ديخر در متغير 
معنى دار نيســت. براى بررسـى همخنى مـاتريس كوواريانس متغير هاى

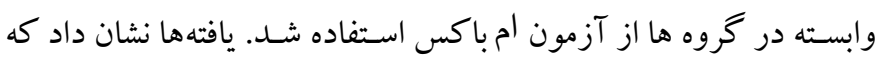

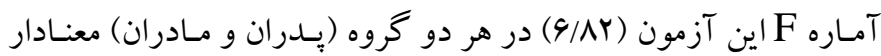

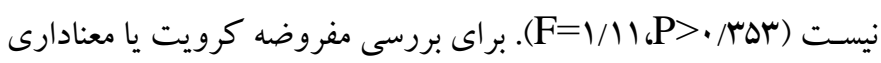
رابطه بين متغيرها از آزمون مجذور خى بارتلت اسـتفاده شــــ كه يافتهها

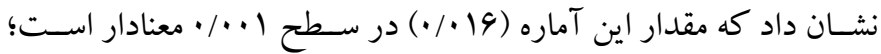

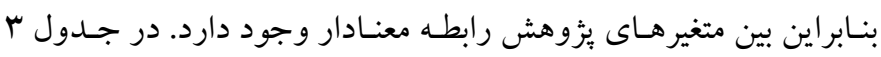

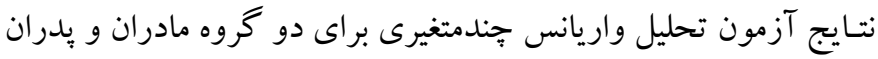
كز ارش شده است.
براى مقايسـه متغيرهاى سـبك هاى دلبستخى والدين در دو گروه، از

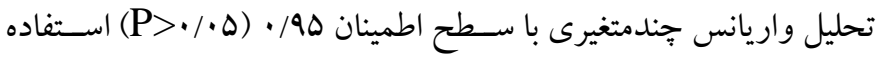

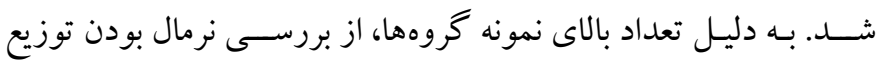

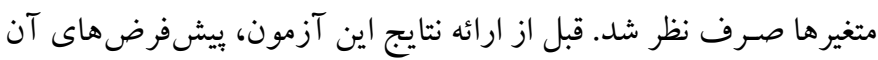

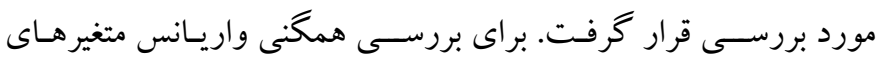

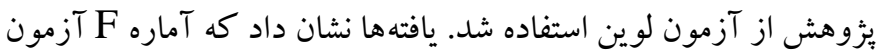

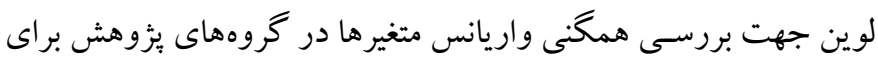

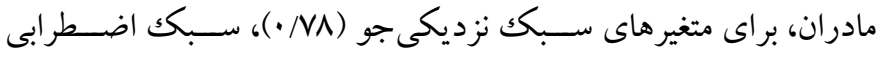

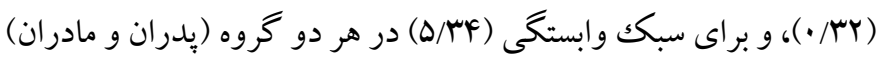

جدول rا: نتايج آزمون تحليل واريانس جندمتغيرى مربوط به دلبستغى در مادران و يدران دو كروه

\begin{tabular}{|c|c|c|c|c|c|c|c|}
\hline اندازه اثر & سطح معنى دارى & d.f1 & d.f1 & $\mathbf{F}$ & آماره & آزمون & كروه \\
\hline.$/ . k$. &.$/ 114$ & 149 & $r$ & $r / \cdot I V$ & $\% 4$. & اثر ييلايى & مادران \\
\hline.$/ .4$. &.$/ 11 f$ & IfG & $r$ & $r / \cdot \mid V$ &.$/ 99$. & لامبداى ويلكز & \\
\hline.$/ .4$. &.$/ 11 F$ & lfe & r & $r / \cdot I V$ &.$/ .41$ & اثر هاتلينگك & \\
\hline.$/ .4$. &.$/ 11 F$ & lf9 & $r$ & $r / \cdot I V$ &.$/ .41$ & بزر گترين ريشه روى & \\
\hline$\cdot / \cdot \Delta$ & $\cdot / \wedge 91$ & IrA & $r$ &.$/ 191$ & $\cdot / \cdot \Delta$ & اثر يِلايى & يدران \\
\hline$\% \cdot \Delta$ & ./194 & IYA & $r$ &.$/ 191$ &.$/ 990$ & لامبداى ويلكز & \\
\hline$\cdot / \cdot \Delta$ & $\cdot / \wedge 9 \wedge$ & IrA & $r$ &.$/ 191$ & $\% \Delta$ & اثر هاتلينك & \\
\hline$\% \cdot \Delta$ & ./194 & IYA & $r$ &.$/ 191$ & $\%$ & بزر گترين ريشه روى & \\
\hline
\end{tabular}

همبجنين بين ســـك هاى والدكرى و ســبك هاى دلبســــى والدين دو كروه، تفاوت معنادارى مشاهده نشد.

نتيجه به دست آمده در اين مطالعه در بخش رضايت مندى زناشويى

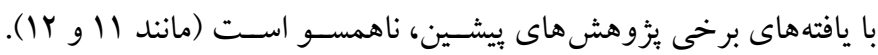
دليـل اين تنـاقض ممكن اســت برخى روش هـاى آمـارى همـانـــ طرح يثوهش يا نمونه گيرى، جامعه آمارى، نوع برسشنامه هاى استفاده شده، و نظاير آن باشد. در نتيجه با اطمينان كاملى نمى توان قضاوت كرد كه واقعاً تفاوت معنادارى از نظر شـاخص هاى رضـايت زناشـويى بين والدين با و بـدون رفتار ناخن جويدن، وجود ندارد؛ زيرا همان طور كه يثوهشهاى بيشـين نيز نشـان دادند مادران و يدران كود كان فاقد مشـكلات رفتارى، نمر ات بالاترى در رضـايت مندى زناشـويى نسـبت به سـاير و الدين دارند. نتيجـهـ اينكـه انجـام مطالعات بيشــتر در اين موضــوع در جارجوبـهاى
بـا توجـه بـه نتـايج جـدول س، آمـاره F تحليـل واريانس جندمتغيرى بررسـى تفاوت كروهها در سـبك دلبستيَى، در هيج كدام از آزمونها معنى دار نيســت؛ بنابر اين مى توان كفت كه بين گروهها در ســـك هاى

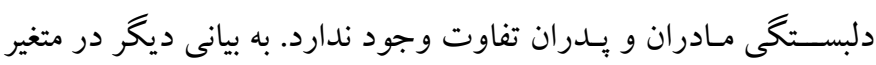
دلبســكَى، بين ســبك مادران كود كان با و بدون رفتار ناخن جويدن و يــران كودكـان بـا و بــدون رفتـار ناخن جويدن، تفاوت معنادارى وجود نذاشته است.

\section{بحث و نتيجه كيرى}

اين بزظوهش به منظور مقايســه رضــايتـمندى زناشــويى، ســـك هاى والدگرى، و سبككهاى دلبستخى والدين داراى كود كان با و بدون رفتار ناخن جويدن انجام شـــ. تحليل دادههاى به دســت آمده نشــان داد بين رضـايت مندى زناشـويى والدين دو گروه، تفاوت معنادارى وجود ندارد. 
قابل ذكر اسـت كه در اجراى اين بثزوهش، محدوديتهاى بسـيارى

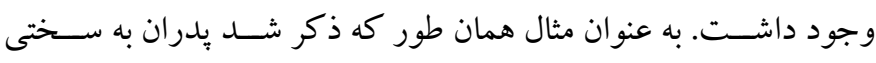

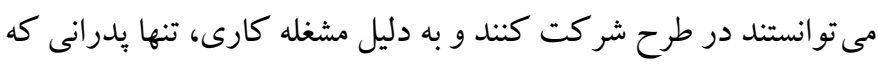
در شـيفت عصر شاغل نبودند و مى تو انستند در مدرسه حضور ييدا كنند

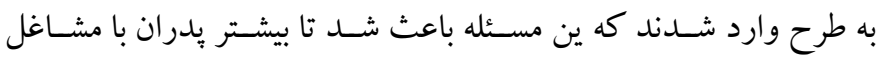

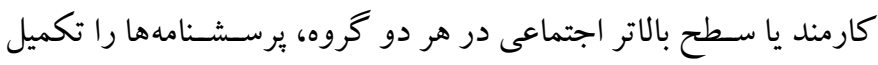

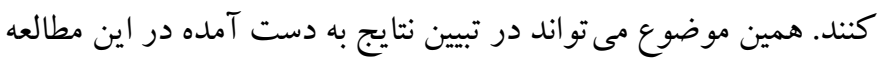

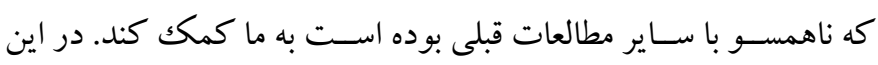

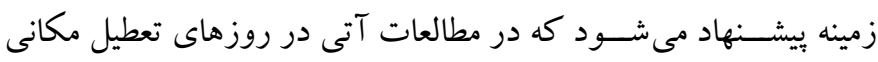

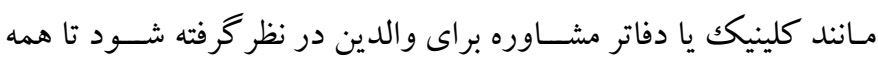
يدران شاغل نيز بتواند در صورت تمايل در مطالعه شركت كنند تا بتوان نتايج دقيق ترى به دست آورد. للازم به ذكر اسـت كه انتخاب كاملاً تصـادفى افر اد نمونه در تمامى دورد

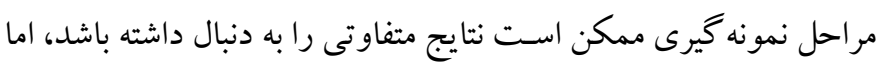

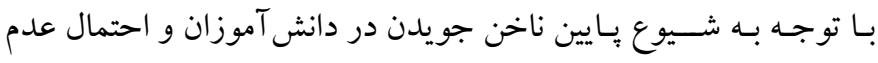

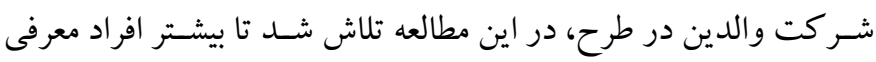

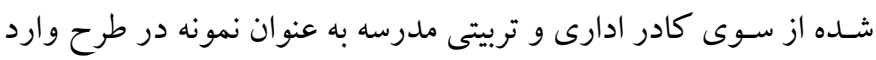

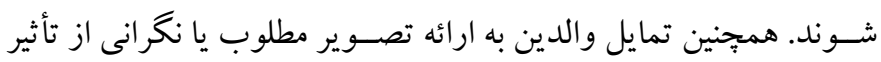
ياسخ ها بر وضعيت تحصيل فرزندانشان، احتمالا از عوامل دخيل در نتايج

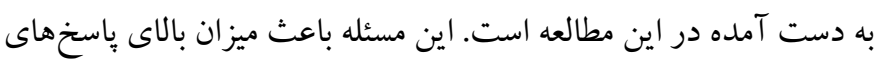
خالى در برســـنامه ها نيز شده بود. در اين صورت به به احتمال زياد، اجبار

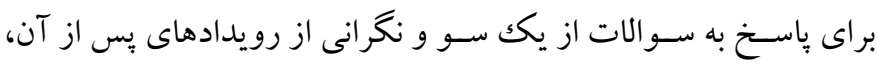

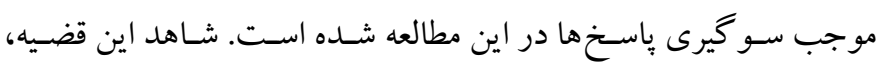

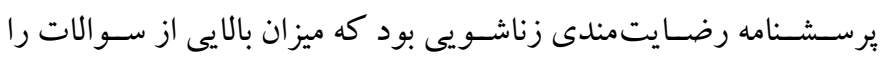

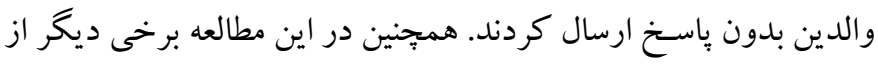

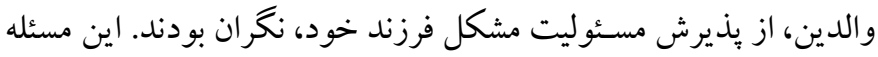

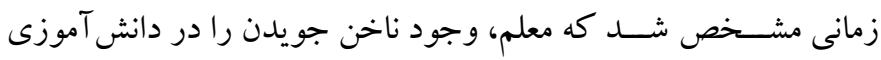

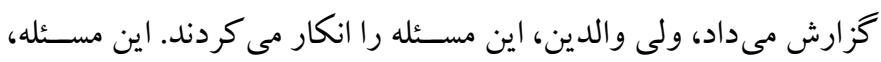
وجود مقاومت را در والدين براى يذيرش مشكل رفتارى فرزندشان نشان مىداد كه مى تواند اعتبار پاسخها را كاهش دهد. نتيجه اينكه در مطالعات

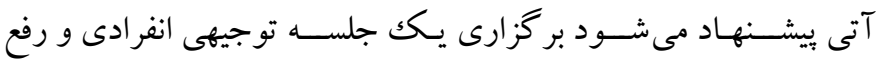

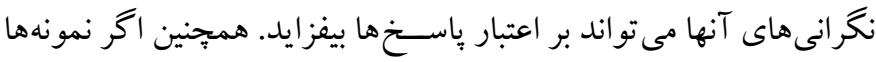

روش شناختى متفاوت تا اندازهاى مى تواند به شفاف شدن يافته ها، كمكك كند. - n همجِنين نتايج مقايسه دو گروه والدين در متغير سبكهاى والدگرى،

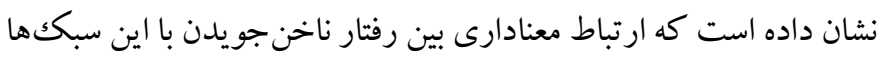
وجود ندارد كه با يافتهاى يُزوهشهاى بيشين، متناقض است (Y) (Y).

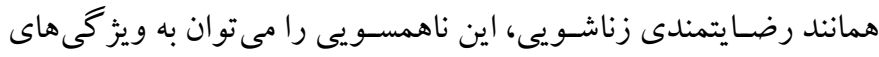

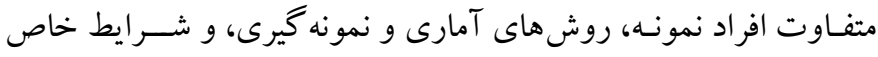

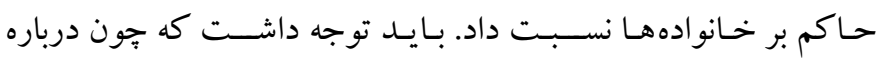
ناخن جويدن كودكك و عوامل والد-محور، يزٔوهشى كاملاً مشـابه انجام

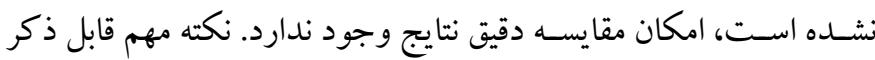

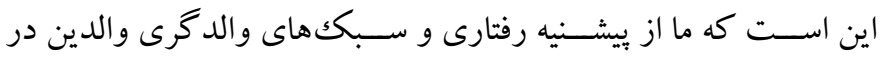

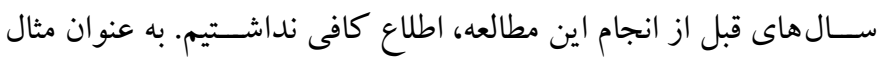

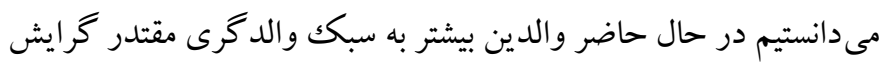

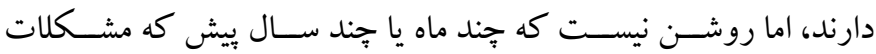

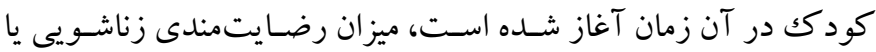
سبكك والدگرى والدين، جه بوده است. اين نكته زمانى، اهميت بيشترى

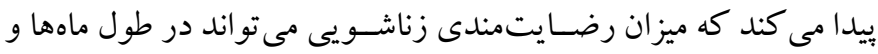

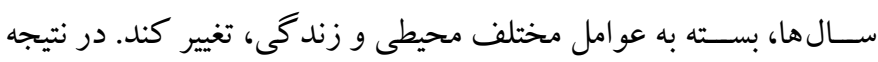
بهتر اسـت در مطالعات آتى در جلسـاتى انفرادى از والدين، شـرح حال

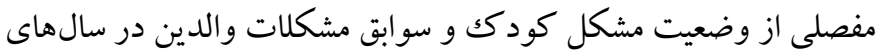
قبل، گر فته شود.

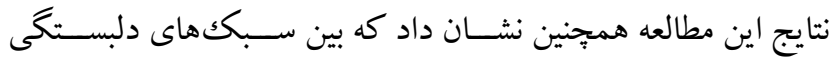

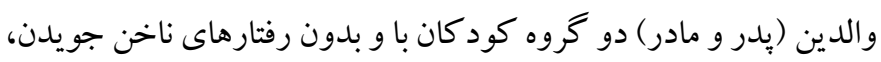
تفــاوت معنـادار وجود نــدارد كـه اين يـافتـه مطـابق بـا نتـايج برخى از

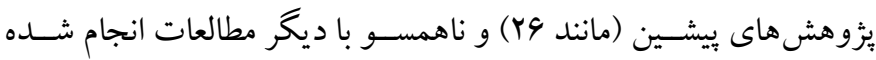
(مانند TD) اسـت. در اين زمينه بايد توجه داشت كه انجام مطالعات بيشتر

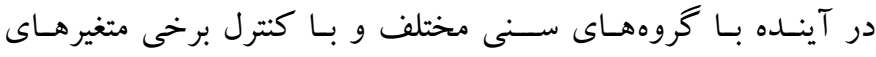

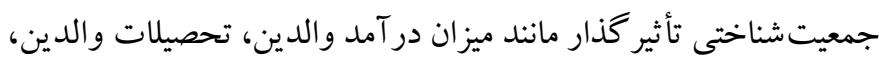

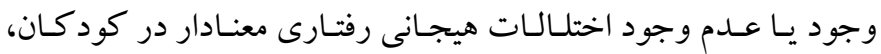
وضـعيت تحصـيلى كود كان، ســطح روابط بين فردى، و ... مى تواند به روشـن شــدن نتايج به دسـت آمده و در نتيجه تعميمدهى دقيق يافتها

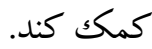


روش شــناختى ذكر شـــه و همجنين مجموعه نكات مطروحه در بخش تبيين و تفسير اين مقاله، مورد ارزيابى و استفاده قرار كيرد.

تشكر و قدردانى: اين مقاله برگرفته از پايان نامه كارشناسى ارشد خانم فاطمه غلامى در رشته روانشناسى بالينى دانشگاه علوم يزشكى شيراز با راهنمايى د كتر احمد غنىزاده و مشـاورت آقاى غلامرضا دهبزر گى با كد 9V99 است. همجنين مجوز اجراى آن بر روى افراد نمونه از سوى اداره آموزش و يرورش شهر شيراز

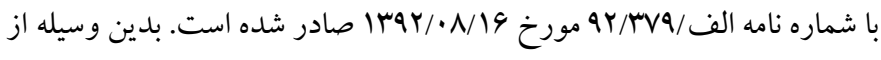
مســؤلان اداره آموزشويرورش به خصــوص كارشــناس هســته مشــاوره كه همـاهنكى با مدارس جهت اجراى اين مطالعه را انجام دادند و همجنين از كادر

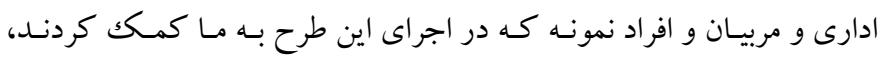
صميمانه تشكر و قدردانى مى شود. تضاد منافع: اين بئوهش براى نويسند گان هيج گونه تضاد منافعى نداشته است.
از كلينيكك ها و مر اكز درمانى انتخاب شوند و فضاى روانى آرامشبخش براى والدين ايجاد شـود، شايد بتوان انتظار داشت كه ياسخ هاى شفافتر و قابل اعتمادترى را ارائه كنند. در يايان يِيشـنهاد مى شـود در كنار يرسشنامه، از مصاحبه، مشاهده، و بررسـىهاى كيفى عميقتر براى جمع آورى دادهها اسـتفاده شـود. براى مثـال مشــاهـده فر اوانى و شــدت رفتـار نـاخن جويدن كودك در طى روزهاى متوالى توســ بزظوهشــر مى تواند تصـوير بهترى از وضـعيت

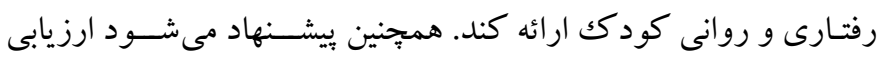
سـبك هاى والدگرى،، دلبستكى، و رضايتمندى زناشويى تنها با تكيه بر دادههاى حاصـل از يرسـشـنامه نباشد و استفاده از مصاحبه بالينى در كنار اسـتفاده از برسـشنامه مى تواند مفيدتر و مؤثرتر باشد. نتيجه اينكه نتايج به دســـت آمـده در اين مطـالعهـ بهتر اســت در برتو محسدوديستهــاى 


\section{References}

1. Maraz A, Hende B, Urban R, Demetrovics Z. Pathological grooming: evidence for a single factor behind trichotillomania, skin picking and nail biting. Plos One. 2017; 12(9): e0183806. [Link]

2. Marouane O, Ghorbel M, Nahdi A, Necibi A, Douki $\mathrm{N}$. New approach to managing onychophagia. Case Report in Dentistry. 2016; 5475462: 1-5. [Link]

3. Bezawada N, Raoul G T L-E, Currie GP. Onychophagia and a missed opportunity. QJM. 2016; 109(12): 825-825. [Link]

4. Salimi H, Sabzian S, Jozai SK. The effectiveness of habit reversal training on the nail-biting disorder. Quarterly Journal of Social Work. 2016; 4(4): 29-34. [Persian]. [Link]

5. Herdiyati Y, Marhani ND. A description of nail biting habit in elementary school children. OnLine Journal of Biological Sciences. 2017; 17(2): 66-69. [Link]

6. Siddiqui J, Qureshi S, Marei W, Mahfouz T. Onychophagia (nail biting): a body focused repetitive behavior due to psychiatric co-morbidity. Journal of Mood Disorders. 2017; 7(1): 47-49. [Link]

7. Vyas T. Effect of chronic nail biting and non-nail biting habit on the oral carriage of enterobacteriaceae. Journal of Advanced Medical and Dental Sciences Research. 2017; 5(7): 53-60. [Link]

8. Desai T. Trichotillomania (hair pulling), nail biting disorder, and skin picking: understand the basics. Bucks County Anxiety Center; 2018, pp: 1-3. [Link]

9. Zaheri F, Dolatian M, Shariati M, Simbar M, Ebadi A, Azghadi SBH. Effective factors in marital satisfaction in perspective of Iranian women and men: a systematic review. Electron Physician. 2016; 8(12): 3369-3377. [Link]

10.Asghari-Ganji A, Navabinejad S, Vardanyan K. The effectiveness of teaching intervention internal locus of control on increasing marital adjustment and satisfaction. Iranian Journal of Health Sciences. 2015; 3(1): 60-68. [Link]

11. Motamedi F, Ghobari Bonab B, Abrgham Z. Forgiveness, marital satisfaction and mental health of parents of children with intellectual disability and normal children. Journal of Exceptional Children. 2016; 16(4): 27-38. [Persian]. [Link]

12.Mohammadi MR, Farokhzadi F, Alipour A, Rostami R, Dehestani M, Salmanian M. Marital satisfaction amongst parents of children with attention deficit hyperactivity disorder and normal children. Iran J Psychiatry. 2012; 7(3): 120-125. [Link]
13. Alami M, Hadi Bahrami E, Asadolah Tooyserkani M. The role of dimensions of marital satisfaction in prediction oppositional defiant disorder and conduct disorder. Journal of Exceptional Children. 2012; 12(3): 61-68. [Persian]. [Link]

14.Aghapoor M, Aghdasi AN. A study of the relationship between marital conflict and child affectivebehavioral psychopathological symptoms. Woman and Study of Family. 2010; 3(9): 27-35. [Persian]. [Link]

15. Van der Geest KE, Mérelle SYM, Rodenburg G, Van de Mheen D, Renders CM. Cross-sectional associations between maternal parenting styles, physical activity and screen sedentary time in children. BMC Public Health. 2017; 17: 753. [Link]

16. Moghaddam MF, Validad A, Rakhshani T, Assareh M. Child self-esteem and different parenting styles of mothers: a cross-sectional study. Archives of Psychiatry and Psychotherapy. 2017; 19(1): 37-42. [Link]

17.Thabet AA, Qrenawi TS. The relationship between parenting styles and fear among Palestinian children in the Gaza strip. EC Psychol Psychiatr. 2017; 2(2): 61-71. [Link]

18. Smetana JG. Current research on parenting styles, dimensions, and beliefs. Curr Opin Psychol. 2017; 15: 19-25. [Link]

19.Bornstein L, Bornstein MH. Parenting styles and child social development. In: Tremblay RE, Barr RG, Peters RD, editor. Encyclopedia on early childhood development. Montreal, Quebec: Centre of Excellence for Early Childhood Development; 2007: pp: 1-4. [Link]

20.Tarkeshdooz S, Farokhzad P. The relationship between children behavioral disorders with parenting styles and attachment styles. Salamat Ijtimai (Community Health). 2017; 4(2): 118-126. [Persian]. [Link]

21. Shafipour SZ, Sheikhi A, Mirzaei M, KazemnezhadLeili E. Parenting styles and its relation with children behavioral problems. Journal of Holistic Nursing and Midwifery. 2015; 25(2): 49-56. [Persian]. [Link]

22.Aminpour M, Mamsharifi M, Bayazidi S, Ahmadzadeh M. Relation of attachment styles and marital adjustment among young couples. World Sci News. 2016; 29: 111-123. [Link]

23.Amani R, Majzoobi MR, Azadi Fard S. Mother-infant attachment style as a predictor of depression among female students. Journal of Midwifery and Reproductive Health. 2017; 5(1): 834-841. [Link] 
24.Bajoori E, Saravani MR. The comparative of role of attachment styles and parent's quality of life and academic achievement of high school children. Biosci Biotechnol Res Commun. 2017; 1: 203-208. [Link]

25. Howard K, Martin A, Berlin LJ, Brooks-Gunn J. Early mother-child separation, parenting, and child wellbeing in early head start families. Attach Hum Dev. 2011; 13(1): 5-26. [Link]

26. Ghobari Bonab B, Estiri Z. A comparative study on personality characteristics and attachment style in mothers of children with and without autism. Journal of Exceptional Children. 2006; 6(3): 787-804. [Persian]. [Link]
27.Azimian J, Piran P, Jahanihashemi H, Dehghankar L. Investigation of marital satisfaction and its relationship with job stress and general health of nurses in Qazvin, Iran. Electron Physician. 2017; 9(4): 4231-4237. [Link]

28. Minaei A, Nikzad S. The factor structure and validity of the Persian version of the Baumrind parenting style inventory. Journal of Family Research. 2017; 13(49): 92-108. [Persian]. [Link]

29. Fujimori A, Hayashi H, Fujiwara Y, Matsusaka T. Influences of attachment style, family functions and gender differences on loneliness in Japanese university students. Psychology. 2017; 8(4): 654-662. [Link] 